\title{
PENGEMBANGAN BAHAN AJAR (MODUL) SEJARAH INDONESIA BERBASIS CANDI- CANDI DI BLITAR UNTUK MENINGKATKAN KESADARAN SEJARAH
}

\author{
Wafiyatu Maslahah \\ Pendidikan IPS, Fakultas Psikologi dan Ilmu Pendidikan, Universitas Islam Raden Rahmat Malang
}

Lailatul Rofiah

Pendidikan IPS, Fakultas Psikologi dan Ilmu Pendidikan, Universitas Islam Raden Rahmat Malang

Abstrak

Penelitian ini memiliki tujuan jangka panjang yakni supaya pembelajaran sejarah Indonesia lebih bermakna dan mampu menanamkan sikap kepada peserta didik. Target yang ingin dicapai dalam penelitian ini yakni dapat menghasilkan sebuah produk bahan ajar (modul) yang dapat digunakan untuk melengkapi pembelajaran sejarah Indonesia pada Madrasah Aliyah Swasta Se-Kabupaten Blitar serta dapat menumbuhkan kesadaran sejarah pada siswa. Rencana penelitian akan menggunakan model pengembangan (Research and Development). Langkah-langkah yang akan dilakukan yaitu 1.) studi pendahuluan dilakukan dengan menerapkan pendekatan deskriptif kualitatif, 2.) tahap observasi untuk mengumpulkan informasi tentang candi-candi di Blitar, 3.) tahap pengembangan desain bahan ajar (modul) yaitu a.) Mendesain, b.)Validasi desain oleh ahli, c.) Revisi desain, d.) Uji coba produk, e.) Mengevaluasi dan merevisi produk, f.) Uji coba pemakaian, g.) Revisi produk, h.) Produksi, 4.) tahap uji efektifitas bahan ajar (modul) untuk meningkatkan keasadaran sejarah dengan eksperimen quasi dengan tahap sebagai berikut a.) Uji normalitas, b.) Uji Homogenitas, dan b.) Uji t. Hasil dari penelitian ini bahwa 1.) pengembangan bahan ajar (modul) sejarah indonesia berbasis candi-candi di kabupaten blitar untuk meningkatkan kesadaran sejarah memiliki kelayakan karena telah dilakukan validasi oleh validator dengan diperoleh nilai ratarata 3,75. Dilakukan uji terbatas dan uji lebih luas dengan masing-masing rata-rata yang diperoleh 3,5 dan 3,775. 2.) Efektifitas pengembangan bahan ajar (modul) sejarah Indonesia berbasis candi-candi di Kabupaten Blitar yang dikembangkan untuk meningkatkan kesadaran sejarah sangat efektif diketahui bahwa $t_{\text {hit }}: 4,823>t_{\text {tab }} 1,683$ dengan nilai signifikansi 0,000 < 0,05 maka dapat disimpulkan bahwa terdapat perbedaan antara kelompok eksperimen dan kelompok kontrol.

Kata Kunci: modul,candi, kesadaran sejarah

\section{Pendahuluan}

Pendidikan yang bermutu akan mencetak sumber daya manusia yang handal dan mampu bersaing di era global. Salah satu upaya pemerintah dalam meningkatkan mutu pendidikan dalam menghadapi tantangan globalisasi yakni diterbitkannya kurikulum 2013. Pada kurikulum tersebut upaya pengembangan mutu dalam mata pelajaran sejarah juga dilakukan. Mata pelajaran sejarah berubah nama menjadi sejarah Indonesia. Muatan materi ajar pelajaran sejarah difokuskan pada sejarah Indonesia supaya generasi muda tetap memiliki perilaku kesadaran sejarah, nasionalisme dan cinta tanah air di era global. Penjelasan Ammert dkk (2017: 5) bahwa formal education is an arena where historical and moral conciousness are expected to be cultivated along the lines stipulated in the curriculum, but in school as well as elsewhere people also learn-and even more-informal education. Penanaman kesadaran sejarah dalam pendidikan formal 
demikian dapat muncul pada siswa jika terjadi pembelajaran yang bermakna di dalam mata pelajaran sejarah Indonesia.

Pembelajaran akan menjadi bermakna jika dalam pembelajaran terdapat kesinambungan antara guru dan siswa. Sejalan dengan pendapat Agung (2013: 3) bahwa, pembelajaran dapat diartikan sebagai proses kerja sama antara guru dan siswa dalam memanfaatkan segala potensi dan sumber yang ada. Terwujudnya kerja sama yang baik diawali dengan interaksi yang baik. Interaksi utama dalam pembelajaran yakni guru, siswa dan bahan ajar. Pada pembelajaran bahan ajar merupakan sarana terjadinya interaksi antara guru dan siswa.

Bahan ajar merupakan bagian yang sangat penting dari suatu proses pembelajaran secara keseluruhan (Ramdani 2012: 50). Bahan ajar merupakan unsur yang penting dalam kegiatan pembelajaran karena mengandung rambu-rambu materi yang akan diajarkan. Tanpa adanya bahan ajar guru tidak dapat berinteraksi dengan siswa dalam memberikan materi pembelajaran. Bahan pembelajaran yang harus dikuasai oleh guru tidak hanya bahan inti sebab pembelajaran akan menjadi kaku. Perlu adanya pengembangan bahan ajar supaya pembelajaran lebih menarik.

Pada pembelajaran sejarah Indonesia diperlukan bahan pembelajaran yang jelas sebab terkait dengan periodisasi atau pembabakan waktu sejarah. Jika dalam pembelajaran tersebut guru tidak memiliki bahan ajar maka pembelajaran menjadi tidak sitematis. Selain itu perlu dilakukan pengembangan bahan ajar supaya pelajaran sejarah Indonesia lebih menarik dan tidak membosankan. Pembelajaran sejarah di sekolah juga memiliki anggapan yang negatif yakni memiliki daya tarik yang rendah pada siswa bahkan dianggap sebagai mata pelajaran yang membosankan serta tidak memiliki manfaat dan kegunaan. Hal itu menunjukkan indikator bahwa siswa tidak memiliki kesadaran sejarah.

Agar pembelajaran sejarah Indonesia tidak kaku, terjadi interaksi yang baik antara guru dan siswa, serta mampu menumbuhkan kesadaran sejarah di era globalisasi maka guru dapat mengembangkan bahan ajar berupa modul berbasis lingkungan yang berupa objekobjek sejarah di daerah siswa. Bahan ajar (modul) yang dikembangkan lebih mempermudah siswa mehami materi. Peserta didik bisa menganalisis objek-objek sejarah dengan dikaitkan pada materi pelajaran yang ada di sekolah.

Selain itu peserta didik akan lebih tertarik dalam mempelajari sejarah Indonesia karena mengeksplore objek-objek sejarah. Tidak adanya bahan ajar yang mengakomodir materi sejarah membuat peserta didik relatif kesulitan untuk memahami peristiwa sejarah (Lazmihfa dkk., 2014: 74). Fenomena pembelajaran sejarah Indonesia yang kurang bermakna 
terjadi pada Madrasah Aliyah (MA) Swasta di Kabupaten Blitar. Hasil observasi awal berdasarkan wawancara kepada pengawas Kementrian Agama Kabupaten Blitar menunjukkan beberapa permasalahan terkait pembelajaran sejarah Indonesia yaitu (1) pada proses pembelajaran yang sudah menerapkan kurikulum 2013 guru hanya menggunakan buku paket dan Lembar Kerja Siswa (LKS) (2) kurangnya sarana pembelajaran yang berupa media pembelajaran (3) siswa menganggap pembelajaran sejarah menjenuhkan dan susah dipahami (4) siswa tidak memahami peninggalan-peninggalan sejarah di Kabupaten Blitar sehingga kesadaran sejarah tidak muncul pada individu.

Berdasarkan fenomena tersebut, untuk mewujudkan pembelajaran yang bermutu dan bermakna pada MA Swasta di Kabupaten Blitar perlu adanya pengembangan dalam proses pembelajaran yakni pengembangan bagan ajar. Harapannya mampu melengkapi informasi utama yang hanya didapatkan dari buku paket dan LKS.

Pengembangan dalam pembelajaran sejarah agar lebih bermakna dan terintegrasi dengan berbagai bidang keilmuan lainnya, sekurang-kurangnya terdapat berbagai bidang yang seyogianya mendapat perhatian (Aman, 2011:7). Pengembangan bahan ajar dalam proses pembelajaran sejarah Indonesia di MA Swasta perhatian dipusatkan pada pengembangan modul. Mengingat keterbatasan ekonomi pihak madrasah dan peserta didik, sarana pembelajaran, serta bahan ajar yang hanya menggunakan buku dan LKS. Solusi pengembangan modul terbaik karena dapat digunakan untuk mendalami materi lebih lanjut. Modul juga dapat dijadikan sebagai wahana yang menyediakan pengalaman yang bersifat self contained dan self directed sehingga siswa dapat berinteraksi dengan materi (bahan pelajaran) dan memperoleh makna tentang belajar tersebut.

Modul yang akan dikembangkan dalam penelitian ini yakni modul berbasis candi-candi di Blitar. Objek sejarah di pusatkan pada candi sebab siswa sangat minim pengetahuan tentang peninggalan Hindu-Buddha yang ada di Blitar. Pengembangan bahan ajar (modul) sejarah Indonesia berbasis objek sejarah candicandi di Kabupaten Blitar akan membantu dalam proses pembelajaran.

Alasannya yakni pertama, problem perekonomian yang menjadikan siswa tidak dapat mengunjungi satu persatu lokasi candi-candi menjadikan siswa terbantu. Kedua, siswa akan mendapatkan makna dalam pembelajaran sejarah Indonesia yang bersumber dari lingkungan disekitar. Hal ini menunjukkan, bahwa fungsi lingkungan merupakan faktor yang penting dalam proses belajar mengajar (Hamalik, 2011: 194). Ketiga, bahan ajar yang relevan dengan kebutuhan siswa di daerah akan 
menjadikan siswa memiliki kesadaran sejarah sehingga ikut serta dalam melestarikan peninggalan-peninggalan sejarah. Hal tersebut sesuai dengan Peraturan Mendiknas No.22 tahun 2006 bahwa salah satu tujuan dari mata pelajaran sejarah di SMA yakni menumbuhkan apresiasi dan penghargaan peserta didik terhadap peninggalan sejarah sebagai bukti peradaban bangsa Indonesia di masa lampau. Monumen sejarah adalah bagian yang sangat penting dari warisan masa lampau. Monumen perlu dipelihara untuk mengabdikan budaya bagi generasi mendatang (Kochhar, 2008: 41).

Fauziah dkk. (2014) dalam penelitiannya yang berjudul Pengembangan Media Interaktif Berbasis Situs Candi di Jawa Tengah Untuk Meningkatkan Hasil Belajar dan Kesadaran Keberagaman Budaya Siswa MAN 1 Kota Magelang, memiliki perbedaan dengan penelitian ini. Penelitian di fokuskan pada sekolah swasta dengan tujuan siswa pada MA Swasta dengan segala keterbatasannya supaya mendapatkan pengetahuan yang sepadan dengan siswa pada sekolah negeri dan dapat menumbuhkan kesadaran sejarah.

Menurut hasil penelitian Lazmihfa dkk. (2014) dengan judul Pengembangan Bahan Ajar Sejarah (Modul) Berbasis Diorama Museum Benteng Vredeburg Untuk Meningkatkan Kesadaran Sejarah Siswa Kelas XI IPS SMA Negeri 1 Kalasan Sleman Yogyakarta, memiliki perbedaan dengan dengan penelitian ini. Fokus kajian dalam penelitian ini yaitu modul candi-candi di Kabupaten Blitar serta pada MA swasta.

Berdasarkan uraian yang sudah dipaparkan, maka akan mengembangkan bahan ajar (modul) berbasis candi-candi di Blitar yang dapat dijadikan sebagai penunjang dalam pembelajaran sejarah Indonesia. Berbasis candi-candi di Blitar akan memunculkan kesadaran sejarah pada peserta didik. Dengan demikian formulasi penelitian yang spesifik adalah Pengembangan Bahan Ajar (Modul) Sejarah Indonesia Berbasis Candi-Candi Di Blitar Untuk Meningkatkan Kesadaran Sejarah.

Penelitian ini bertujuan untuk Mengembangkan dan efektifitas bahan ajar (modul) Sejarah Indonesia berbasis candicandi di Kabupaten Blitar untuk meningkatkan kesadaran sejarah.

\section{Tinjauan Pustaka}

\section{A. Bahan Ajar Modul}

Modul pada dasarnya merupakan bahan ajar yang secara sistematis dengan menggunakan bahasa yang mudah dipahami oleh siswa sesuai dengan tingkat pengetahuan dan usianya agar mereka dapat belajar mandiri atau tanpa bimbingan yang minimal dari guru (Nilasari dkk., 2016: 1399). Berdasarkan hal tersebut modul membuat siswa lebih mandiri dalam belajar disaat minimnya bimbingan dari guru serta harus disusun secara sistematis sesuai 
dengan usia dengan menggunakan bahasa yang mudah dipahami.

Penyusunan sebuah modul pembelajaran diawali dengan urutan kegiatan sebagai berikut (Hamdani, 2011: 221-222):

1. Menetapkan judul modul yang akan disusun.

2. Menyiapkan buku-buku sumber atau referensi yang lain.

3. Melakukan identifikasi terhadap kompetensi dasar, melakukan kajian terhadap materi pembelajarannya, serta merancang bentuk kegiatan pembelajaran yang sesuai.

4. Mengidentifikasi indikator pencapaian kompetensi dan merancang bentuk dan jenis penilaian yang akan disajikan.

5. Merancang format penulisan modul.

6. Penyusunan draft modul.

7. Validasi.

8. Finalisasi.

B. Candi

Menurut Rusdi (2010: 18) menjelaskan bahwa candi biasanya mengacu pada berbagai macam bentuk dan fungsi suatu bangunan. Fungsi bangunan yang dimaksud antara lain adalah sebagai tempat ibadah, pusat pengajaran agama, tempat penyimpanan abu jenazah para raja, tempat pemujaan atau tempat bersemayamnya para dewa, petirtaan (pemandian), dan gapura. Dari fungsi yang telah di paparkan bahwa candi merupakan tempat suci untuk kegiatan keagamaan umat Hindu atau Buddha. Berbagai macam candi yang memiliki wujud dan fungsi tersendiri di jelaskan sebagai berikut:

1. Candi adalah bangunan tempat menyimpan abu jenazah dan memuliakan roh seorang raja dan pembesar yang telah bersatu dengan dewata penitisnya.

2. Candi merupakan tempat penghormatan dan pemujaan dewata atau para arwah nenek moyang.

3. Bangunan suci punden berundak yang dibangun sejak zaman prasejarah dan berorientasi kepada puncak gunung. Bangunan ini dianggap sebagai tempat tinggal arwah leluhur yang berkedudukan setara dewata.

4. Pentirtaan adalah pemandian yang disucikan oleh pemeluk Budha dan Hindu.

5. Gapura sebagai pintu untuk keluiar masuk, baik yang beratap atau tidak.

6. Stupa adalah bangunan khas agama Budha. Merupakan tempat merayakan orang yang telah mencapai nirwana serta menghomati kehidupan sang Budha yang sebelumnya.

7. Umat Hindu menganggap candi sebagai tempat dimana para deata berdiam selama suatu upacara dilakukan.

8. Bagi umat Islam cenderung kepada kepercayaan asli (agami Jawa) dan umat Hindu, bangunan purbakala dipercaya tempat kediaman para arwah leluhur dah roh-roh lain. 
9. Umat Budha berziarah ke bangunan suci sebagai tanda kehirmatan orang-orang yang telah mencapai nirwana dan untuk bermeditasi (Lestari, 2011:8-9).

Menurut Arifin (dalam Arifin, 2015: 14-17) beberapa fakta bahasa yang ditemukan dalam candi Hindu yakni: Bhūrloka, Bhuwahloka, Swargaloka, Lingga, Yoni, Suluran, Jaladara, Makara, Gana, Simbar, Durgamahișāsuramardini, Ganesa, Agastya, Mahakala, Nandiswara, Ratna, Kinara-kinari, dan Naga. Penamaan candi berdasarkan bentuk dikategorikan bagian candi Hindu yang memiliki satu kesatuan yang utuh dan termasuk di dalamnya merupakan ornamen maupun arcanya.

Ciri relief di Jawa Timur dengan Jawa Tengah berbeda. Ciri relief ercandian Jawa Tengah rata-rata berukuran besar, bentuknya natural, proporsi seperti mengikuti patokan tertentu, tiga dimensi, sedangkan Jawa Timur hampir kebalikannya (Soebroto, 2012: 14).

\section{Kesadaran Sejarah}

Historical consciousness becomes a hermeneutic concept that deals with the totality of history and historical undestanding; it take a meta-perspective on history and individual's conceptions of history (Thorp, 2014: 15). Berdasarkan penjelasan terbebut bahwa kesadaran sejarah akan muncul jika kita memahami sejarah secara total (menyeluruh). Karena pemahaman sejarah yang utuh membentuk konsep pemahaman individu tentang sejarah.
Menurut Aman (2011: 34), indikatorindikator kesadaran sejarah dapat dirumuskan mencakup sebagai berikut:

1. Menghayati makna dan hakekat sejarah bagi masa kini dan masa yang akan datang.

2. Mengenal diri sendiri dan bangsanya

3. Membudayakan sejarah bagi pembinaan budaya bangsa.

4. Menjaga peninggalan sejarah bangsa.

\section{Metode Penelitian}

Penelitian ini menggunakan metode penelitian pengembangan (Research and Development) yang digunakan untuk menghasilkan produk tertentu dan menguji keefektifan produk tersebut (Sugiyono, 2013: 407). Produk yang diharapkan dari penelitian ini berupa bahan ajar (modul).

Berikut tahap-tahap dalam penelitian ini yang dilakukan yaitu:

1. Tahap studi pendahuluan dilakukan dengan menerapkan pendekatan deskriptif kualitatif yakni dengan melakukan wawancara terhadap pengawas di Kementerian Agama Kabupaten Blitar.

2. Tahap observasi untuk mengumpulkan informasi tentang candi-candi di Blitar yakni pada dua belas candi antara lain; candi Penataran, candi Sawentar, candi Simping, candi Wringin Branjang, candi Bacem, candi Tepas, candi Gambar Wetan, candi Kotes, candi Kali Cilik, candi Plumbangan, candi Rambut Monte, dan candi Sumbernanas. 
3. Tahap pengembangan desain bahan ajar (modul) yaitu 1.) Mendesain, 2.)Validasi desain, 3.) Revisi desain, 4.) Uji coba produk, 5.) Mengevaluasi dan merevisi produk, 6.) Uji coba pemakaian, 7.) Revisi produk , 8.) Produksi.

4. Tahap uji efektifitas bahan ajar (modul) untuk meningkatkan kesadaran sejarah dengan eksperimen quasi dengan tahap sebagai berikut 1.) Uji normalitas, 2.) Uji Homogenitas, dan 3.) Uji t.

Penelitian ini dilakukan pada Madrasah Aliyah Swasta Se-Kabupaten Blitar. Terletak di Provinsi Jawa Timur. Blitar merupakan wilayah yang kaya akan peninggalan sejarah salah satunya peninggalan Hindu-Budha yang berupa candi. Populasi dalam penelitian yakni seluruh Madrasah Aliyah Swasta di Kabupaten Blitar. Sample dalam penelitian ini diambil dengan menggunakan metode Cluster Random Sampling.

Menurut Riduwan dan Akdon (2007: 241) Random sampling adalah cara pengambilan sample dari anggota populasi dengan menggunakan acak tanpa memperhatikan strata (tingkatan) dalam anggota populasi tersebut. Cluster sampling adalah prosedur sampling yang ideal ketika peneliti merasa tidak mungkin mengumpulkan daftar semua elemen yang membentuk populasi (Creswell, 2010: 218). Didapatkan sample Madrasah Aliyah Assalam Jambewangi Selopuro sebagai kelas eksperimen sejumlah 40 siswa dan
Madrasah Nurul Islam Wates sebagai kelas kontrol sejumlah 40 siswa. Pada kelas X IIS kelompok wajib dalam kurikulum 2013. Pada uji coba terbatas dilakukan dengan mengambil lima orang siswa dari perwakilan masing-masing kelas. Uji coba terbatas dan uji kelas lebih luas dilakukan pada kelas eksperimen.

Teknik yang digunakan dalam mengumpulkan data seperti berikut ini:

1. Wawancara

Wawancara dilakukan untuk mengumpulkan informasi awal dalam penelitian. Wawancara dilakukan kepada pengawas Madrasah dengan asumsi pengawas lebih mengetahui kondisi Madrasah Aliyah Swasta di Kabupaten Blitar. Wawancara juga digunakan untuk mengumpulkan informasi tentang candicandi di Blitar dengan mewawancarai juru pelihara candi.

2. Angket

Angket disusun dengan menggunakan kaidah-kaidah distribusi skor sebagai berikut:

Tabel 1. Skor dengan Skala Likert

\begin{tabular}{|c|l|c|}
\hline No. & \multicolumn{1}{|c|}{ Jawaban } & Skor \\
\hline 1. & Sangat Setuju & 5 \\
\hline 2. & Setuju & 4 \\
\hline 3. & Tidak Mempuyai Pilihan & 3 \\
\hline 4. & Tidak Setuju & 2 \\
\hline 5. & Sangat Tidak Setuju & 1 \\
\hline
\end{tabular}

(Sumber : Furchan, 2011: 280)

Dalam hal ini angket kesadaran sejarah akan di bagikan kepada siswa kelas 
X IIS kelompok wajib kurikulum 2013 di MA Assalam Jambewangi Selopuro Blitar dan MA Nurul Islam Wates. Sebelum dibagikan angket telah dilakukan penilaian kelayakan oleh validator angket yang juga merupakan validator bahan ajar (modul) yakni guru, pengawas, ahli materi, dan ahli bahasa. Setelah angket dinilai oleh validator kemudian diuji cobakan pada kelas yang tidak diberi perlakuan dengan jumlah butir angket sebanyak 50. Selanjutnya dilakukan validitas angket dengan penghitungan menggunakan bantuan program SPSS 20, rumus koefisien korelasi Product Moment dari Karl Pearson.

Biasanya dalam pengembangan dan penyusunan skala-skala psikologi, digunakan harga koefisien korelasi yang minimal sama dengan 0,30. Dengan demikian, semua pernyataan yang dimiliki korelasi dengan skor skala kurang dari pada 0,30 dapat kita sisihkan dan penyataanpernyataan yang akan diikutkan dalam skala sikap diambil dari aitem-aitem yang memiliki korelasi 0,30 ke atas dengan pengertian semakin tinggi korelasi itu mendekati angka 1,00 maka semakin baik pula konsistensinya (Azwar, 2013: 153).

Penelitian ini kriteria butir soal angket yang dipakai jika $r_{i y} \geq 0,30$. Hasil validitas angket dari 50 butir diperoleh 40 butir angket yang valid. Langkah selanjutnya setelah dilakukan uji validitas kemudian uji reliabilitas angket. Untuk mengetahui tingkat korelasi dapat menggunakan daftar sebagai berikut:

a. 0,80-1,00 reliabilitas sangat tinggi.

b. $0,60-0,80$ reliabilitas tinggi.

c. 0,40-0,60 reliabilitas sedang.

d. 0,20-0,40 reliabilitas rendah.

e. 0,00-0,20 reliabilitas sangat rendah (Azwar, 184: 2013).

Kriteria yang digunakan dalam penelitian ini yakni dikatakan reliabel jika $\alpha$ $\geq 0,70$. Setelah dilakukan penghitungan menggunakan bantuan SPSS 20 diperoleh reliabilitas 0,905 Demikian dapat dinyatakan bahwa angket reliabel.

Teknik analisis data yang digunakan yaitu dengan menggunakan pendekatan kualitatif dan kuantitatif. Data berupa saran dan kritik dari ahli/pakar dan siswa dianalisis dengan pendekatan kualitatif dan kuantitatif. Data kelayakan modul dan pendapat mengenai kesesuaian modul diolah dengan deskriptif kualitatif. Uji normalitas dilakukan untuk mengetahui apakah populasi berdistribusi normal.

Uji normalitas pada penelitian ini menggunakan program SPSS 20 yaitu uji Kolmogorov Smornov. Pada penelitian ini uji homogenitas dilakukan dengan bantuan program SPSS 20. Bantuan yang digunakan yaitu uji Test of Homogeneity of Variances. Sedangkan uji t dilakukan dengan bantuan program SPSS 20 dengan uji Independent Samples Test. Berikut rancangan penelitian pengembangan yang dilakukan pada 
penelitian ini dengan mengembangkan rancangan di dalam Sugiyono (2013: 409) sebagai berikut:

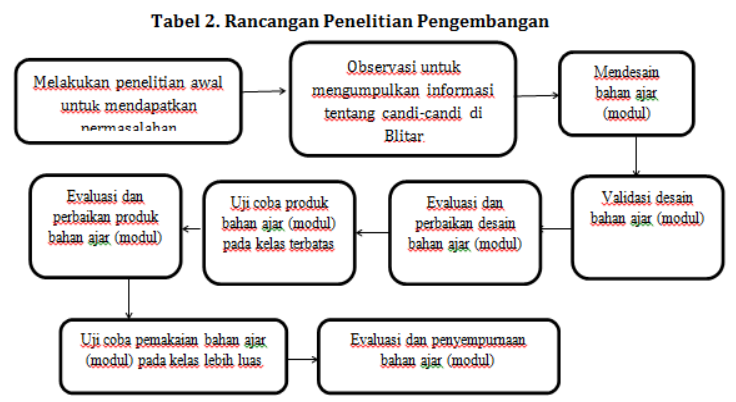

Hasil dan Pembahasan

A. Pengembangan bahan ajar (modul) sejarah Indonesia berbasis candicandi di Kabupaten Blitar.

Pengembangan bahan ajar (modul) sejarah Indonesia berbasis candi-candi di Kabupaten Blitar disusun dengan menghimpun data dengan mewawancarai juru pelihara candi meliputi candi Penataran, candi Sawentar, candi Simping, candi Wringin Branjang, candi Bacem, candi Tepas, candi Gambar Wetan, candi Kotes, candi Kali Cilik, candi Plumbangan, candi Rambut Monte, dan candi Sumbernanas. Desain bahan ajar/modul candi-candi di Blitar sebagai berikut:
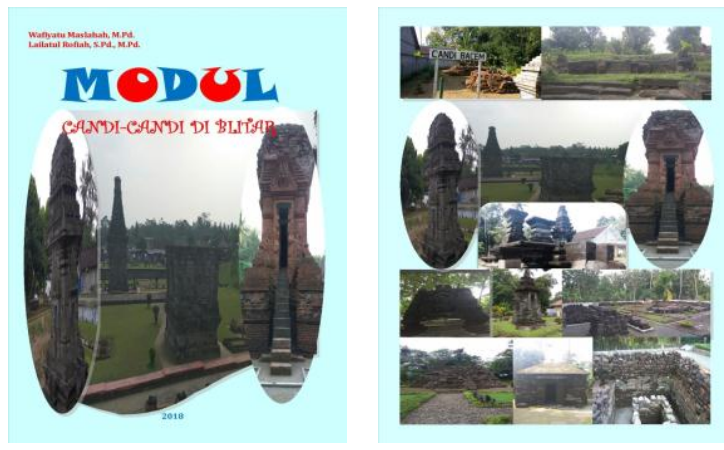

Gambar 1. Desain Bahan Ajar (Modul)
Berbagai macam candi yang memiliki wujud dan fungsi tersendiri di jelaskan sebagai berikut (Lestari, 2011:8-9).

1. Candi adalah bangunan tempat menyimpan abu jenazah dan memuliakan roh seorang raja dan pembesar yang telah bersatu dengan dewata penitisnya.

2. Candi merupakan tempat penghormatan dan pemujaan dewata atau para arwah nenek moyang.

3. Bangunan suci punden berundak yang dibangun sejak zaman prasejarah dan berorientasi kepada puncak gunung. Bangunan ini dianggap sebagai tempat tinggal arwah leluhur yang berkedudukan setara Dewata.

4. Pentirtaan adalah pemandian yang disucikan oleh pemeluk Budha dan Hindu.

5. Gapura sebagai pintu untuk keluiar masuk, baik yang beratap atau tidak.

6. Stupa adalah bangunan khas agama Budha. Merupakan tempat merayakan orang yang telah mencapai nirwana serta menghomati kehidupan sang Budha yang sebelumnya.

7. Umat Hindu menganggap candi sebagai tempat dimana para deata berdiam selama suatu upacara dilakukan.

8. Bagi umat Islam cenderung kepada kepercayaan asli (agami Jawa) dan umat Hindu, bangunan purbakala dipercaya tempat kediaman para arwah leluhur dah roh-roh lain. 
9. Umat Budha berziarah ke bangunan suci sebagai tanda kehirmatan orang-orang yang telah mencapai nirwana dan untuk bermeditasi.

Pada penelitian ini candi-candi yang ada yakni candi Hindu yang berfungsi sebagai tempat ibadah dan makam atau penyimpan abu jenazah. Setelah dilakukan uji validasi bahan ajar (modul) diperoleh hasil bahwa memiliki kelayakan karena telah dilakukan validasi oleh validator dengan nilai rata-rata 3,75 . Selain dilakukan penilaian oleh validator juga dilakukan uji coba kelas terbatas dengan jumlah siswa 9 orang dan uji coba kelas lebih luas dengan jumlah siswa 40 orang. Pada uji coba terbatas memiliki total nilai 35 dengan ratarata nilai yakni 3,5 sedangkan uji coba lebih luas memiliki jumlah nilai keseluruhan 151 dengan rata-rata nilai 3,775.

Menurut Nilasari dkk. (2016: 1399) Modul pada dasarnya bahan ajar yang secara sistematis dengan menggunakan bahasa yang mudah dipahami oleh siswa sesuai dengan tingkat pengetahuan dan usianya agar mereka dapat belajar mandiri atau tanpa bimbingan yang minimal dari guru. Berdasarkan data yang telah diperoleh bahwa siswa dapat memahami dengan baik bahan ajar (modul) yang dikembangkan dalam penelitian ini. Karena modul telah disusun sesuai dengan bahasa yang mudah dipahami siswa tingkat Madrasah Aliyah. Selain bahasa yang mudah dipahami juga disusun berdasarkan usia siswa.

\section{B. Efektifitas pengembangan bahan ajar (modul) sejarah Indonesia berbasis candi-candi di Kabupaten Blitar}

Efektifitas pengembangan modul sejarah Indonesia berbasis candi-candi Kabupaten Blitar yang dikembangkan untuk meningkatkan kesadaran sejarah sangat efektif setelah dilakukan uji normalitas, uji homogenitas dan uji hipotesis (uji $t$ ). Uji normalitas digunakan untuk mengetahui apakah data yang digunakan berdistribusi normal atau tidak. Data suatu variabel dinyatakan normal apabila uji normalitas menghasilkan probabilitas lebih besar dari 0,05. Berdasarkan perhitungan dengan bantuan program SPSS 20 diperoleh nilai signifikansi sebesar 0,132 untuk kelas eksperimen dan 0,361 untuk kelas kontrol. Maka dapat disimpulkan bahwa data berdistibusi normal baik kelas eksperimen maupun kelas kontrol karena masingmasing nilai signifikansi $>0,05$. Uji homogenitas dilakukan untuk mengetahui apakah beberapa varian populasi adalah sama atau tidak.

Dasar pengambilan keputusan adalah jika nilai signifikansi (sig) lebih besar dari 0,05 maka varian dari dua kelompok atau lebih adalah sama. Sebaliknya apabila nilai signifikansi kurang dari 0,05 maka varian dari dua kelompok atau lebih tidak sama. Berdasarkan perhitungan dengan menggunakan program SPSS 20 diperoleh nilai signifikansi (sig) sebesar 0,247 sehingga dapat disimpulkan bahwa data 
kesadaran sejarah siswa baik kelas eksperimen maupun kontrol berasal dari populasi yang homogen atau mempunyai varian yang sama.

Pengujian hipotesis dalam penelitian ini menggunakan uji-t karena sampel yang digunakan dalam penelitian ini merupakan sampel bebas yang tidak berhubungan. Adapun hipotesis yang diuji dalam penelitian ini adalah efektifitas pengembangan bahan ajar (modul) sejarah Indonesia berbasis candi-candi di Kabupaten Blitar untuk meningkatkan kesadaran sejarah Berdasarkan hasil analisis perhitungan menggunakan program SPSS 20, diketahui bahwa $t_{\text {hit }}: 4,823>t_{\text {tab }}$ 1,683 dengan nilai signifikansi 0,000 0,05 maka dapat disimpulkan bahwa terdapat perbedaan antara kelompok eksperimen dan kelompok kontrol.

Historical consciousness becomes a hermeneutic concept that deals with the totality of history and historical undestanding; it take a meta-perspective on history and individual's conceptions of history (Thorp, 2014: 15). Sesuai dengan pernyatan tersebut bahwa setelah siswa memahami konsep secara utuh tentang peninggalan sejarah berupa candi-candi di Blitar melalui bahan ajar (modul), terdapat peningkatan kesadaran sejarah.

Hal tersebut berbeda dengan hasil yang diperoleh dari kelas kontrol yang tidak dilakukan pengembangan bahan ajar (modul) dalam pembelajaran sejarah mendapatkan.

\section{Penutup}

\section{A. Kesimpulan}

Berdasarkan hasil penelitian yang dilakukan maka kesimpulannya adalah pengembangan bahan ajar (modul) sejarah indonesia berbasis candi-candi di Kabupaten Blitar memiliki kelayakan karena telah dilakukan validasi materi, bahasa maupun guru dengan diperoleh nilai ratarata 3,75 . Sedangkan untuk uji coba terbatas penilaian rata-rata 3,5 , dan uji lebih luas memiliki rata-rata nilai 3,775. Untuk efektifitas pengembangan bahan ajar (modul) sejarah Indonesia berbasis candi Kabupaten Blitar sangat efektif. Terbukti $t_{\text {hit: }}$ $4,823>t_{\text {tab }} 1,683$ dengan nilai signifikansi $0,000<0,05$. Maka disimpulkan bahwa terdapat perbedaan antara kelompok eksperimen dan kelompok kontrol.

\section{B. Saran}

Sebagai bahan pertimbangan maka setelah penelitian ini dilakukan terdapat beberapa saran, antara lain:

1. Guru dapat mengembangkan bahan ajar (modul) lebih lanjut dalam proses pembelajaran Sejarah Indonesia.

2. Pihak sekolah hendaknya memotivasi guru untuk mengembangkan bahan ajar (modul) guna memenuhi keterbatasan materi ajar.

3. Para peneliti dapat mengembangkan bahan ajar (modul) berbasis candi-candi 
di Blitar atau berbasis yang lainnya sehingga dapat mengatasi problem pembelajaran Sejarah Indonesia.

\section{Daftar Pustaka}

Agung, Leo S. 2013. Perencanaan Pembelajaran Sejarah. Yogyakarta. Ombak.

Aman. 2011. Model Evaluasi Pembelajaran Sejarah. Yogyakarta. Ombak.

Ammert, Niklas, dkk. 2017. Bridging Historical and Moral Consciousness: Promises and challenges. Historical Encounters; A Journal of Historical Consciousness, Historical Cultures, and History Education, 4 (1), 1-13.

Arifin, Ferdi. 2015. Representasi Simbol Candi Hindu Dalam Kehidupan Manusia: Kajian Linguistik Antropologis. Jurnal Penelitian Humaniora, 16 (2), 12-20.

Azwar, Syaifuddin. 2013. Sikap Manusia Teori dan Pengukurannya. Yogyakarta. Pustaka Pelajar.

Creswell, John W. 2009. Research Design Pendekatan Kualitatif, Kuantitatif, dan Mixed. Yogyakarta. Pustaka Pelajar.

Fauziah, A.S. dkk. 2014. Pengembangan Media Interaktif Berbasis Situs Candi di Jawa Tengah Untuk Meningkatkan Kesadaran Sejarah Siswa Kelas XI IPS SMA Negeri 1 Kalasan Sleman Yogyakarta. Jurnal Historika, 15 (2), 83-92.

Furchan, Arief. 2011. Pengantar Penelitian dalam Pendidikan. Yogyakarta. Pustaka Pelajar.

Hamalik, Oemar. 2011. Proses Belajar Mengajar. Bandung: Bumi Aksara.

Hamdani. 2011. Strategi Belajar Mengajar. Bandung: Pustaka Setia.

Kochhar, S.K. 2008. Pembelajaran Sejarah; Teaching of History. Jakarta: Grasindo.

Lazmihfa, dkk. 2014. Pengembangan Bahan Ajar Sejarah (Modul) Berbasis Diorama Museum Benteng Vredeburg Untuk Meningkatkan Kesadaran
Sejarah Siswa Kelas XI IPS SMA Negeri 1 Kalasan Sleman Yogyakarta. Jurnal Historika, 15 (2), 71-82.

Lestari, Garsinia. 2011. Mengenal Lebih Dekat: Candi Nusantara. Jakarta. Pacu Minat Baca.

Maryanto, D.A. 2007. Mengenal Candi. Jakarta. Citra Aji Parama.

Nilasari, Efi, dkk. 2016. Pengaruh Penggunaan Modul Pembelajaran Kontekstual Terhadap Hasil Belajar Siswa Kelas V Sekolah Dasar. Jurnal Pendidikan, 1(7), 1399-1404.

Ramdani, Yani. 2012. Pengembangan Instrumen dan Bahan Ajar Untuk Meningkatkan Kemampuan Komunikasi, Penalaran, dan Koneksi Matematis Dalam Konsep Integral. Jurnal Penelitian Pendidikan, 13 (1), 14-52.

Riduwan dan Akdon. 2007. Rumus dan Data Dalam Statistika. Bandung. Alfabeta.

Rusdi. 2010. Wajah Cantik Nan Misterius Borobudur dan Prambanan. Jogjakarta: Flashbooks

Soebroto, R.G.B. 2012. Kajian Estetika Yang Beda Relief Candi Jawa Timur. Jurnal Arsitektu Universitas Bandar Lampung, 2 (2), 14-27.

Soetarno. 2007. Aneka Candi Kuno di Indonesia. Semarang. Effhar Offset Semarang.

Sugiyono. 2013. Metode Penelitian Pendidikan Pendekatan Kuantitatif, Kualitatif, dan R\&D. Bandung. Alfabeta.

Thorp, Robert. 2014. Historical Consciousness, Historical Media, History Education. Omslag-Sandra Olsson. Umea Universitet. 